the garden city movement, and the Fellowship of the New Life incubated a number of experimental schools.

To-day the community planners have a real relevance. This is an age of community centres, satellite towns, group dynamics, sociometry. One of the major intellectual attractions is the rediscovery of a community of Essenes. Another is the current preoccupation in psychology and psychiatry with what is called group therapy. Sociologists, too, are affected : Pitirim Sorokin has established at Harvard a Research Centre in Social Altruism. The Christian Church itself has acquired an enhanced awareness of the importance of community relationships. Utopian literature is well known; what is not so well known are the literary by-products of Utopist endeavour. One is "The Pilgrim's Progress" and another is "The Vicar of Wakefield".

\title{
OBITUARY
}

\section{Dr. G. R. Bisby}

GUy Richard Bisby, plant pathologist and mycologist, who died at his home in Staines, Middlesex, on September 3, was born at Brookings, South Dakota, on August 17, 1889. He came of farming stock, and like many of his contemporaries worked his way through the university, graduating B.S. from South Dakota State College, 1912, and becoming an M.A. of Columbia University, 1917. In the following year he was awarded the degree of Ph.D. by the University of Minnesota for a thesis on Fusarium diseases of potato. During 1916-20 he was instructor, then assistant professor in plant pathology in the University of Minnesota, and later, until 1936, professor of plant pathology and plant pathologist in the Manitoba Agricultural College, Winnipeg (where he took Canadian nationality). He spent $1921-22$ in England at the Imperial Bureau of Mycology, and in 1937 returned to the Imperial (now Commonwealth) Mycological Institute, Kew, where he became senior assistant mycologist-a post he held until his retirement in 1954 .

The author of more than a hundred books and papers on plant pathology and mycology, Dr. Bisby is best remembered as a taxonomist. His strength in this field was an ability to make up his mind, and this, combined with a systematic approach and prodigious industry, gave him the knack of bringing to a conclusion any project on which he might engage. In a notable series of collaborations he set the pace and brought to fruition catalogues of the fungi of Manitoba, India and Ceylon, lists of the
Pyrenomycetes, Hyphomycetes and rusts of Great Britain, and a "Dictionary of the Fungi".

$\mathrm{He}$ was interested in many different groups of fungi, and although he will be perhaps particularly remembered for his studies on the Hysteriales, he made important contributions to our knowledge of the Hyphomycetes, especially Stachybotrys and Trichoderma. He was in charge of the rust collections at the Commonwealth Mycological Institute, and his ready help in identifying specimens and his prompt replies to inquiries will be remembered with gratitude by many overseas plant pathologists. One result of Dr. Bisby's interests in nomenclature was the most useful little book, "The Taxonomy and Nomenclature of Fungi", 1945 (2nd edition, 1953).

of a retiring disposition, Bisby was seen at his best talking 'shop' in his room at the Institute or in his garden (which was as well-ordered and as weedfree as his taxonomy); but he had many interests, including chess, archæology, the clarinet and, like many taxonomists, stamp collecting. One of his chief hobbies, due in part to a wide circle of friends in North America, was correspondence, and many mycologists welcomed the sight of his clear handwriting and the signature written with such dash and flourish.

Dr. Bisby received a number of honours. He was vice-president of the British Mycological Society, a member emeritus of the American Phytopathological Society, and in 1956 the University of Minnesota awarded him the gold medal for outstanding achievements.
G. C. Arnsworth

\section{NEWS and VIEWS}

\section{The Woodrow Wilson National Fellowship Foundation}

SIR HUGH TAYLOR, dean emeritus of the Graduate School of Princeton University, has been appointed first president of the Woodrow Wilson National Fellowship Foundation. Dr. Hans Rosenhaupt, assistant provost of Columbia University, has been appointed national director of the Foundation. The headquarters of the Foundation are at 32 Nassau Street, Princeton, New Jersey.

The Woodrow Wilson National Fellowship Foundation was founded in 1957 with the main objective of recruiting outstanding students for careers as college teachers. In 1957, after the Wilson Fellowships had been jointly underwritten for five years by thirtyseven American universities and by grants from the Carnegie Corporation and General Education Board, the present programme began with a grant of
24,500,000 dollars from the Ford Foundation for a five-year period. During the first year of its operation the Foundation granted fellowships to nearly a thousand students in the United States and Canada who will graduate this year.

\section{H. W. M. Olbers}

Heinrich Wilhelm Matthias Ombers, who was born at Arbergen, a village on the Weser near Bremen, two centuries ago on October 11, 1758, was an amateur astronomer who, even after his discoveries had been accepted and acclaimed, continued his medical practice. The son of a minister, he studied mathematics and medicine at the University of Göttingen, where he graduated M.D. in 1780 with a thesis entitled "De oculi mutationibus internis". While still a student, he devised the first satisfactory method of calculating the orbit of a comet in 1779 . 